

\title{
Sterben für den Glauben
}

Ursprung, Genese und Aktualität des Martyriums in Christentum und Islam

Author: Thorsten Hoffmann

Der Begriff »Märtyrer« erfährt aktuell eine geradezu inflationäre Verwendung: Popstars und Prominente werden ebenso zu Märtyrern stilisiert wie islamistische Selbstmordattentäter. Eine intensive Auseinandersetzung mit der Theologie des Martyriums im Christentum und im Islam hilft dabei, dieses Phänomen zu verstehen und kritisch zu hinterfragen. Das Martyrium rührt an die Grundlagen des Menschseins, denn es gründet wesentlich in der Frage, wofür ein Mensch bereit ist, sein Leben zu geben. In diesem Sinne ist das Martyrium der »Ernstfall« des Glaubens, aber auch eine radikale Infragestellung weltlicher Machtansprüche. Das Buch stellt die wichtigsten Etappen der Entstehung einer Theologie des Martyriums im Christentum und im Islam vor, analysiert die Texte beider Religionen und verfolgt die Differenzierung und Problematisierung des Martyriums. Systematisch-theologische Fragestellungen werden ebenso behandelt wie die Verbindung von Martyrium und Terrorismus. Davon ausgehend versucht das Buch Antworten auf die hochaktuelle Frage zu finden, ob Kämpfer und Selbstmordattentäter tatsächlich als Märtyrer gelten können.

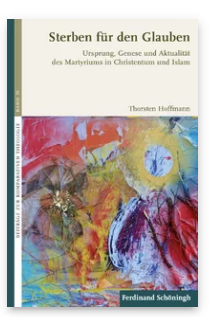

Pages: XVI +448 Seiten

Language:

German

Subjects:

Comparative

Religion \&

Religious

Studies,

Religious

Studies

Publisher: Brill |

Schöningh

Series:

Beiträge zur

Komparativen

Theologie,

Volume: 30

E-Book (PDF)

Released online:

04 Dec 2017

ISBN: 978-3-

657-78735-7

List price

Paperback

Publication date:

o1 Dec 2017

ISBN: 978-3-

5o6-78735-4

List price 
Thorsten Hoffmann studierte Katholische Theologie in Trier sowie Toronto und absolvierte eine journalistische Ausbildung in Frankfurt a. Main.

For more information see brill.com

Order information: Order online at brill.com +44 330 333 0049 | customerservices@brill.com Submission information: brill.com/authors

Titles published by Brill | Fink, Brill | mentis or Brill | Schöningh: +49(o)71 5413279216 | brill@brocom.de 